Volume 7

Number 1 Fall 2019 Symposium Edition

Pharmaceutical Innovation, Patent Protection,

Article 3 and Regulatory Exclusivities

2-9-2021

\title{
The Biologics Price Competition and Innovation Act 10-A \\ Stocktaking
}

Yaniv Heled

Georgia State University College of Law, heledreviewer@gmail.com

Follow this and additional works at: https://scholarship.law.tamu.edu/journal-of-property-law

Part of the Intellectual Property Law Commons

\section{Recommended Citation}

Yaniv Heled, The Biologics Price Competition and Innovation Act 10--A Stocktaking, 7 Tex. A\&M J. Prop. L. 81 (2021).

This Symposia Article is brought to you for free and open access by Texas A\&M Law Scholarship. It has been accepted for inclusion in Texas A\&M Journal of Property Law by an authorized editor of Texas A\&M Law Scholarship. For more information, please contact aretteen@law.tamu.edu. 


\title{
The Biologics Price Competition and Innovation Act at 10-A STOCKTAKING
}

\author{
Yaniv Heled ${ }^{\dagger}$
}

\begin{abstract}
On March 23, 2010, President Obama signed into law the Biologics Price Competition and Innovation Act (BPCIA) as part of the Patient Protection and Affordable Care Act ("Obamacare"). The purpose of BPCIA was to create for biologics a regime similar to that of the Drug Price Competition and Patent Term Restoration Act (Hatch-Waxman Act) and, in so doing, to open biologics markets to competition and, subsequently, lower the price of these expensive and increasingly important pharmaceuticals. Using original data, this Essay takes stock of the decade that has passed since the enactment of BPCIA. This Essay surveys the state of competition in United States biologics markets, entry of follow-on biologics into these markets, and the effects such entry has had on biologics prices.

This Essay's main findings are that, as of March 23, 2020-exactly ten years since the signing of BPCIA into law-the FDA has approved a total of 26 follow-on biologics deemed biosimilar to 9 original products (ratio: 2.63 follow-on/original products), with only 16 of these deemed biosimilar to 7 original products (ratio: 1.78 followon/original products) actually available on the market. None of these follow-on products have been approved as interchangeable with their reference products, which means that substitution of the 7 original products with one of their 16 approved biosimilars cannot be done

DOI: https://doi.org/10.37419/JPL.V7.I1.3

\footnotetext{
$\dagger$ Associate Professor, Georgia State University College of Law; J.S.D. 2011, LL.M. 2004 Columbia Law School; LL.B. 2000, Undergraduate Diploma in Biology 2000 Tel Aviv University. This Essay is based in part on my comments at the Texas A\&M Journal of Property Law Symposium on Pharmaceutical Innovation, Patent Protection, and Regulatory Exclusivities. I am grateful to Jonathan Darrow, Ana Santos Rutschman, and Liza Vertinsky for their comments on earlier drafts. Any remaining flaws and mistakes are mine alone. I am also grateful to Pam Brannon, John Duddles, and Alessandra Palazzolo for their assistance with the research for this Essay.
} 
automatically. The price of these products was $10 \%-37 \%$ lower than the price of the original biologic, with the average price savings being $24 \%$ or $27 \%$. All 35 approved follow-on and reference products are owned by a total of 11 pharmaceutical companies. The number of years of market exclusivity of the 9 original biologics before the approval of the first biosimilar ranged between 13.5-28.92 with an average of 18.27 years or 15.33-29.42 with an average of 19.87 years before the launch of the first competing biosimilar.

This Essay further puts forward a new method of measuring comparative levels of competition in drug markets by comparing the ratio of total approved follow-on products per total approved original products at certain critical benchmarks. Using this measurement tool, this Essay compares BPCIA's track record with the levels of competition in small-molecule drugs before and after the HatchWaxman Act, showing that that BPCIA significantly underperforms in comparison and fails to instigate levels of competition that would lead to significant price drops and increase access to biologics in the United States. A short survey of the most likely reasons for BPCIA's underperformance follows.

This Essay concludes by presenting the following question: if BPCIA's current track record is (still) not enough to convince that it is failing to meet its goals, what more would it take to reach such a conclusion, and how much longer should policymakers wait before it is possible to surmise that BPCIA in its current form has failed to significantly increase access to biologics in the United States?

I. INTRODUCTION 82

II. BPCIA AT 10 - THE NUMBERS................................................ 84

III. NOT A HATCH-WAXMAN SUCCESS STORY ................................. 87

IV. REASONS FOR BPCIA's POOR TRACK RECORD........................... 93

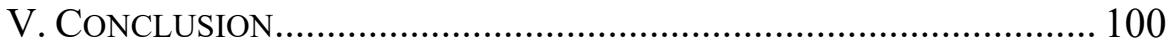

\section{INTRODUCTION}

On March 23, 2010, President Obama signed the Biologics Price Competition and Innovation Act (BPCIA) as part of the Patient 
Protection and Affordable Care Act ("Obamacare"). ${ }^{1}$ The purpose of BPCIA was to create for biologics a regime similar to that of the Drug Price Competition and Patent Term Restoration Act (Hatch-Waxman Act $)^{2}$ and, in doing so, to open biologics markets to greater competition and, subsequently, lower the price of these expensive and increasingly important pharmaceuticals. ${ }^{3}$ Ten years later, competition in biologics remains scant and prices high. Biologics product markets are highly concentrated in the hands of a few large pharmaceutical companies that compete over market share with small to minimal effect on product prices. While some believe that it might still be "too soon to give up" on BPCIA, ${ }^{4}$ others - including the undersignedhave seen this as a sign of BPCIA's failure. ${ }^{5}$

Written for the Texas A\&M University School of Law Symposium on Pharmaceutical Innovation, Patent Protection, and Regulatory Exclusivities, this Essay takes stock of the decade that has passed since the enactment of BPCIA. Relying on new data, this Essay surveys the state of competition in United States biologics markets, entry of follow-on biologics ("biosimilars") into these markets, and the effects such entry has had on biologics prices. This Essay further puts forward a new method of measuring comparative levels of competition in drug markets by comparing the ratio of total approved follow-on products per approved original products. Using this measurement tool, this Essay compares BPCIA's track record with the

1. The Patient Protection and Affordable Care Act, Pub. L. No. 111-148, $\S \S$ 7001-7003, 124 Stat. 119, 804-23 (2010).

2. Drug Price Competition and Patent Term Restoration Act of 1984, PUB. L. No. 98-417, 98 Stat. 1585 (codified as amended in scattered sections of 15, 21, 35 \& 42 U.S.C. (2012)) [hereinafter Hatch-Waxman Act].

3. See e.g., Andrew W. Mulcahy et al., Biosimilar Cost Savings in the United States, 7 RAND HEALTH Q. 3, 6 (2018) ("[W]hile only 1-2 percent of the U.S. population is treated with a specialty drug each year - a category that includes biologics and other complex, often expensive drugs, biologics alone accounted for 38 percent of U.S. prescription drug spending in 2015 due to their high cost per dose, and for 70 percent of drug spending growth between 2010 and 2015."

4. See, e.g., Jonathan J. Darrow, Biosimilar Approvals and the BPCIA: Too Soon to Give Up, HEALTH AFFAIRS BLOG (July 19, 2019), https://www.healthaffairs.org/do/10.1377/hblog20190718.722161/full/

[https://perma.cc/6ADQ-27RQ].

5. See e.g., Preston Atteberry et al., Biologics Are Natural Monopolies (Part 1): Why Biosimilars Do Not Create Effective Competition, HeAlth AFFAIRS BloG (Apr. 15, 2019), https://www.healthaffairs.org/do/10.1377/hblog20190405.396631 /full/ [https://perma.cc/F4US-YPFF]; Yaniv Heled, Follow-On Biologics are Set Up to Fail, 2018 U. ILL. L. REV. ONLINE 113, 115 (2018). 
state of competition in small-molecule drugs before and after the Hatch-Waxman Act, concluding that BPCIA significantly underperforms in comparison and fails to instigate the kind of competition that would lead to significant drops in the prices of biologics in the United States. A short survey of the most likely reasons for BPCIA's underperformance follows.

This Essay concludes by presenting this question: if BPCIA's current track record is (still) not enough to convince that it is failing to meet its goals of significantly increasing access to biologics in the United States, what more would it take to reach such a conclusion, and how much longer should policymakers wait?

\section{BPCIA AT 10-THE NUMBERS}

After significant delays in BPCIA's implementation, ${ }^{6}$ in March 2015, the FDA approved the first follow-on version of a biologic: the biosimilar Zarxio. ${ }^{7}$ Between that time and March 23, 2020 - exactly ten years since BPCIA was signed - the FDA approved a total of 26 follow-on biologics that were deemed biosimilar to 9 original products ("reference products" $\left.{ }^{\prime}\right) .{ }^{9}$ None of these 26 biosimilars have been approved as or deemed interchangeable with

6. See discussion infra Part IV.

7. Drugs@FDA: FDA-Approved Drugs, U.S. FOOD \& DRUG ADMIN., https://www.accessdata.fda.gov/scripts/cder/daf/index.cfm?event=overview.proces s\&ApplNo=125553 [https://perma.cc/N2V6-D7VH] (last visited May 13, 2020) (citing the approval date of Zarxio as March 6, 2015).

8. See 42 U.S.C. § 262(i)(4) (2018) ("The term 'reference product' means the single biological product licensed under subsection (a) against which a [follow-on] biological product is evaluated...").

9. See infra Appendix A, Table I [hereinafter Table I]. According to the FDA's Purple Book, by that date the FDA had approved about 270 original biologics for marketing in the United States (including 17 products whose licenses were later voluntarily revoked). See FDA, Purple Book: Database of Licensed Biological Products, https://purplebooksearch.fda.gov/advanced-search [https://perma.cc/3SWT-QPR6] (last visited May 31, 2020). The number of approved biologics is exclusive of vaccines, blood products, gene therapies, allergens, and other products approved by the Center for Biologics Evaluation and Research. See Purple Book: Database of Licensed Biological Products, U.S. FoOD \& DRUG ADMIN., https://www.fda.gov/media/89426/download (last accessed June 27, 2020) [https://perma.cc/YB78-P7EK]. The numbers include products that were originally approved as small-molecule drugs but were "deemed" to have been approved as biologics as of March 23, 2020. See infra notes 55-56 and accompanying text; See also List of Approved NDAs for Biological Products that were Deemed to be BLAs on March 23, 2020, U.S. FoOD \& DRUG ADMIN. (2020), https:/www.fda.gov/media/119229/download [https://perma.cc/C8B2-3JK5]. 
their reference product, ${ }^{10}$ which means that substitution of the 9 original products with one of their approved biosimilars cannot be done automatically, but rather require the prescribing physician to specifically prescribe the biosimilar. ${ }^{11}$ As of May 2020, only 16 of these 26 approved biosimilars, which were deemed biosimilar to 7 reference products, were actually available on the market. ${ }^{12}$ The price of these products was $10 \%-37 \%$ lower, on average, than the price of the original biologic, ${ }^{13}$ with the average price savings being $24 \%$ or $27 \%$. $^{14}$

Eight pharmaceutical companies owned the 26 approved biosimilars. ${ }^{15}$ Four companies owned the 9 original products with which these biosimilars sought to compete. ${ }^{16}$ In total, competition in biologics occurred between 11 pharmaceutical companies (with Amgen owning both original and follow-on products). The ratio of original product owners to follow-on product owners is 1:2, suggesting that concentration levels in biologics product markets remain high even after original products lose their exclusivity protections.

The 9 original biologics for which biosimilars have been approved had between 1-5 approved biosimilars with an average of 2.63 approved biosimilars for each original product and 1.78 launched biosimilars per original product. ${ }^{17}$

10. Non-interchangeable pharmaceuticals are, by their nature, not fungible and therefore produce little competition. See infra notes 48-52 and accompanying text.

11. See Heled supra note 5, at 125-26.

12. See infra Table I.

13. Data is based on prices listed on the websites Drugs.com and GoodRx.com on May 7, 2020. See Appendix A, Table II. According to GoodRx.com (but not Drugs.com), as of April 2020, the price of Pfizer's Retacrit - the only approved biosimilar for Amgen's original biologics Epogen and Procrit, constituted savings of $67 \%$ and $80 \%$ respectively. See Lauren Chase, A Guide to Biosimilar Prices: How Much They Cost and How You Can Save, GoodRx BLOG (Apr. 14, 2020, 11:32 AM) https://www.goodrx.com/blog/biosimilars-prices-how-much-they-cost-how-tosave/ [https://perma.cc/E5F8-3WAR].

14. Based on average savings calculations from Drugs.com and GoodRx.com respectively. See infra Appendix A, Table III [hereinafter Table III].

15. The companies are Amgen, Boehringer Ingelheim, Celltrion (a subsidiary of Teva), Coherus BioSciences, Mylan GmbH, Pfizer (including its subsidiary Hospira), Samsung Bioepis, and Sandoz. See infra Table I.

16. The companies are AbbVie, Amgen, Genentech (a subsidiary of Roche), and Janssen Biotech (a subsidiary of Johnson \& Johnson). See Table I.

17. See infra Table III. 
The number of years of market exclusivity of the 9 original biologics before the approval of the first biosimilar ranged between 13.5-28.92 with an average of 18.27 years. ${ }^{18}$ The number of years of market exclusivity of these 9 original biologics before the launch of the first competing biosimilar (which virtually always came many months after FDA approval) ranged between 15.33-29.42, and the average years of market exclusivity was $19.87 .{ }^{19}$ The average list price of original biologics for which there already were biosimilars available on the market was $\$ 3,750$ per month. ${ }^{20}$

As these numbers show, ten years after BPCIA's enactment, it has brought only minimal competition to a mere handful of biologics markets and led to small price drops in these markets. ${ }^{21}$ Despite

18. Id. According to research funded by the Pharmaceutical Research and Manufacturers of America (PhRMA) - the pharmaceutical industry's main lobbying arm - the average period of market exclusivity in small-molecule drugs for which follow-on products were approved between 1995-2014 was 12.5 years for products with annual sales greater than $\$ 250$ million and 13.6 years overall. See Henry Grabowski et al., Updated Trends in US Brand-Name and Generic Drug Competition, 19 J. MED. ECON. 836, 836 (2016). This means that exclusivity in biologics for which follow-on products were approved between 2015-2020 was between 1-16.42 and on average 5.77 years longer than the average exclusivity in high-grossing, small-molecule drugs.

19. See infra Table III. This means that exclusivity in biologics for which followon products were launched was between 2.83-16.92 and on average 6.37 years longer than the average exclusivity in high-grossing, small-molecule drugs.

20. See infra Table III. While the list price, namely the price a manufacturer assigns to a drug product, does not reflect discounts that are typically given to health insurance providers, it is still the price that patients without insurance may pay and is the official price tag of a pharmaceutical. See also Chase, supra note 13; $c f$. Joel Lexchin, Affordable Biologics for All, JAMA NETWORK OPEN e204753 (Apr. 27, 2020), https://jamanetwork.com/journals/jamanetworkopen/fullarticle/2764808 [https://perma.cc/Q8UF-JJ4R].

21. As in previous work, by significant/meaningful/true competition I mean levels of competition sufficient to drive down the cost of biologics (and follow-on versions thereof) significantly for payors and patient-consumers, well beyond the $10 \%-37 \%$ price drops currently observed in the United States' biologics markets subsequent to follow-on products' entry. For comparison, in the context of smallmolecule drugs, significant price drops of more than $70 \%$ are typical subsequent to the entry of 4-5 or more generic products into a specific drug market. See New Evidence Linking Greater Generic Competition and Lower Generic Drug Prices, U.S. FOOD \& DRUG ADMIN., https://www.fda.gov/about-fda/center-drugevaluation-and-research-cder/generic-competition-and-drug-prices

[https://perma.cc/RVM9-2375] (last visited May 13, 2020). See also Generic Competition and Drug Prices, U.S. FOOD \& DRUG ADMIN., https://wayback.archiveit.org/7993/20190423134204/https:/www.fda.gov/AboutFDA/CentersOffices/Offi ceofMedicalProductsandTobacco/CDER/ucm 129385.htm [https://perma.cc/3UZJR39Y] (last visited May 13, 2020). 
BPCIA's creation of a regulatory pathway for approval of follow-on biologics, product markets remain highly concentrated in the hands of a few large pharmaceutical companies that compete with each other over market share with small to minimal effect on product prices.

Interestingly, BPCIA's highly controversial and unusually long $^{22}$ twelve-year market exclusivity for original biologics with approved follow-on products ${ }^{23}$ has proved to be shorter, in some cases much shorter, than the actual period during which these original products maintain their exclusivity in their respective productmarkets. Indeed, even the shortest period- 15.33 years in Genentech's Avastin-was 3 years and 4 months longer than the twelve-year exclusivity awarded under BPCIA ${ }^{24}$ the longest period-29.42 years in Amgen's Epogen/Procrit - was nearly 17 years and 6 months longer, 2.5 times BPCIA's twelve-year exclusivity. ${ }^{25}$ These numbers support the proposition that biologics are "natural monopolies" that are not amenable to meaningful competition (or that they are grossly overprotected) and that attempts - such as BPCIA ${ }^{26}$ - to significantly lower biologics' prices through market mechanisms is therefore unlikely to succeed. ${ }^{27}$

\section{Not A HATCH-WAXMAN SUCCESS StORY}

From its inception, BPCIA was fashioned after the same concept that lies at the heart of the Hatch-Waxman Act: that original product prices would drop if follow-on products enter the market and that follow-on products would enter the market if follow-on product

22. See e.g., Heled, supra note 5, at 117 n.28.

23. 42 U.S.C. $\S 262(\mathrm{k})(7)(2018)$.

24. See infra Table III. Notably, twelve years was the length of exclusivity for which the original products industry lobbied prior to the enactment of BPCIA. See, e.g., Safe and Affordable Biotech Drugs: The Need for a Generic Pathway: Hearing Before the H. Comm. on Oversight and Government Reform, 110th Cong. p. 162 (2007) (statement of Henry Grabowski, Ph.D.) (recommending an exclusivity period of at least 10 years). See also Henry Grabowski, Follow-on Biologics: Data Exclusivity and the Balance Between Innovation and Competition, 7 NATURE REV. DRUG DISCOVERIES 479, 486 (2008) (in research funded by PhRMA, arguing that the proper market exclusivity period for biologics should fall between 12.9 and 16.2 years).

25. See infra Table III.

26. An even less complementary view of BPCIA is that from its outset it was illequipped to instill significant competition into biologics markets. See, e.g., Heled, supra note 5 , at $115-19$.

27. See, e.g., Atteberry et al., supra note 5. 
manufacturers are allowed to "piggyback" on earlier approvals of original products and make their own copycat versions. In this way, presumably, follow-on product manufacturers would be able to save the time and money involved in developing an original product and partake in existing, lucrative product markets. This arrangement was implemented in small-molecule drugs starting the 1970s and was, ultimately, streamlined and improved in the Hatch-Waxman Act in 1984. ${ }^{28}$ The Hatch-Waxman Act's success has made it the model that BPCIA was meant to follow.

Nonetheless, a straight up comparison of BPCIA's track record with that of the Hatch-Waxman Act is problematic. As Professor Jonathan Darrow explained, there are several, significant differences between small-molecule drug markets subsequent to the enactment of the Hatch-Waxman Act in 1984 and biologics markets subsequent to the enactment of BPCIA in 2010. By the enactment of the HatchWaxman Act, the FDA had already approved follow-on pharmaceutical product applications for about fourteen years, and both regulators and product developers had acquired significant experience from approval of more than 2,000 such applications. ${ }^{29}$ By contrast, when BPCIA was signed into law, the FDA and product developers had little to no experience in making and comparing follow-on biologics. ${ }^{30}$ Professor Darrow also correctly notes that a numeric

\footnotetext{
28. See Jonathan Darrow, The Rise of Biosimilars: Success of the BPCIA? (Part I), BILl OF HEAlTH BLOG (Jan. 31, 2020), https://blog.petrieflom.law.harvard.edu/2020/01/31/the-rise-of-biosimilars-successof-the-bpcia/ [https://perma.cc/E8RS-FR56] (reviewing the history of approval of follow-on pharmaceutical product applications by the FDA beginning the 1970s). In addition to setting the pathway for approval of follow-on small-molecule drugs in legislation, the Hatch-Waxman Act instituted incentives for development of original and generic drugs and established an intricate patent dispute resolution framework (including the Orange Book) that is interwoven into the pathway for approval of generic versions of original products. See Hatch-Waxman Act, supra note 2.

29. SeeDrugs@FDA Data Files, U.S. Food \& Drug ADMIN.,Drugs@FDA Data Files, https://www.fda.gov/drugs/drug-approvals-and-databases/drugsfdadata-files [https://perma.cc/LC2E-DSFR] (last visited May 31, 2020). The data includes original and supplemental approved applications. The results exclude tentatively approved applications and supplemental applications for which there was an approved original application.

30. See Jonathan Darrow, The Rise of Biosimilars: Success of the BPCIA? (Part I), BILL OF HEALTH BLOG (Jan. 31, 2020), https://blog.petrieflom.law.harvard.edu/2020/01/31/the-rise-of-biosimilars-successof-the-bpcia/ [https://perma.cc/E8RS-FR56]. What little experience product developers have had with development and approval of follow-on biologics was based on their experience in Europe. See discussion infra Part IV.
} 
comparison of the number of original products amenable to follow-on product applications - subsequent to the enactment of the HatchWaxman Act and BPCIA - is not instructive because there were and still are far more original small-molecule products than biologics that are amenable to such applications. ${ }^{31}$ In other words, there were significantly fewer original biologics amenable to follow-on competition in 2010 than there were small-molecule drugs amenable to competition before and subsequent to the enactment of the HatchWaxman Act in 1984.

Still, some insight into the performance of BPCIA may be gleaned from comparing the ratios of approved follow-on products to original products under both regimes around the time that the FDA and the industry are likely to have acquired experience with follow-on applications. Measurement of approved follow-on to original product ratios - which is proposed here for the first time as a means of measuring comparative levels of competition in drug marketsprovides a bird's-eye view of the level of follow-on competition in pharmaceutical markets in their entirety (as opposed to specific drug markets). As such, the measurement of ratios provides a picture of the extent of "openness" of drug markets to competition and the willingness and ability of follow-on manufacturers to develop and pursue approval of follow-on versions of original pharmaceutical products, and the ability of follow-on manufacturers to do so successfully, despite whatever technical and regulatory hurdles they may face. Because the comparison is one of ratios rather than product numbers, the comparison makes it possible to control for differences in sheer number of approved products. Accordingly, a comparison of the number of follow-on applications per number of original products a decade after the commencement of FDA approval of follow-on

\footnotetext{
31. See Jonathan Darrow, The Rise of Biosimilars: Success of the BPCIA? (Part II), BILl OF HEALTH BLOG (Feb. 3, 2020), https://blog.petrieflom.law.harvard.edu/2020/02/03/the-rise-of-biosimilars-successof-the-bpcia-part-ii/ [https://perma.cc/5TFS-YGD4]. There is no good data on how many original biologics were no longer protected by exclusivity and therefore amenable to follow-on competition in 2010. However, it is highly probable that the number of such products was also significantly smaller than the number of products amenable to such competition when the Hatch-Waxman Act was enacted, which was estimated at 125. See id.
} 
applications in biologics and small-molecule drug markets, respectively, may be instructive. ${ }^{32}$

By April 24, 1980 - a decade after the FDA announced that it will accept and start approving follow-on products (Abbreviated New Drug Applications or "ANDA"s) 33 - the FDA approved 1,193 applications for original drugs (New Drug Applications or "NDA"s) and 1,324 ANDAs - a ratio of 1.1 approved follow-on products per 1 original product. ${ }^{34}$ By September 24, 1984 - the day the HatchWaxman Act was signed into law-the FDA approved 1,580 NDAs and 2,131 ANDAs, giving a ratio of 1.35 approved follow-on products per 1 original product. ${ }^{35}$ And by September 24, 1994, ten years after the enactment of the Hatch-Waxman Act, the FDA approved 2,289 NDAs and 4,375 ANDAs, resulting in a ratio of 1.91 approved follow on products per 1 original product. ${ }^{36}$ The trend of ratios of the total numbers of approved ANDAs to NDAs over time may be observed in the following chart:

32. Notably, while the comparison of ratios of follow-on and approved products is useful for overcoming the variance in the number of total approved products under the different regulatory regimes, it may be insufficiently sensitive - at least in its current form - to potentially important differences in the commercial and regulatory realities of small-molecule drugs and biologics, including in the length of exclusivity protections and market sizes. Controlling for these factors, however, is beyond the scope of this work. At the very least, as it currently stands, the comparison supports the proposition that ten years after the enactment of BPCIA levels of competition in biologics markets are not even close to the levels of competition seen in smallmolecule drug markets even before the enactment of the Hatch-Waxman Act, let alone ten years after its enactment.

33. See Food and Drug Administration, Abbreviated Applications, 35 Fed. Reg. 6574, 13540 (Apr. 24, 1970).

34. SeeDrugs@FDA Data Files, U.S. Food \& Drug Admin., Drugs@FDA Data Files, https://www.fda.gov/drugs/drug-approvals-and-databases/drugsfdadata-files [https://perma.cc/LC2E-DSFR] (last visited May 31, 2020) (data includes original and supplemental approved applications). The results exclude tentatively approved applications and supplemental applications for which there was an approved original application.

35. Id.

36. $I d$. 


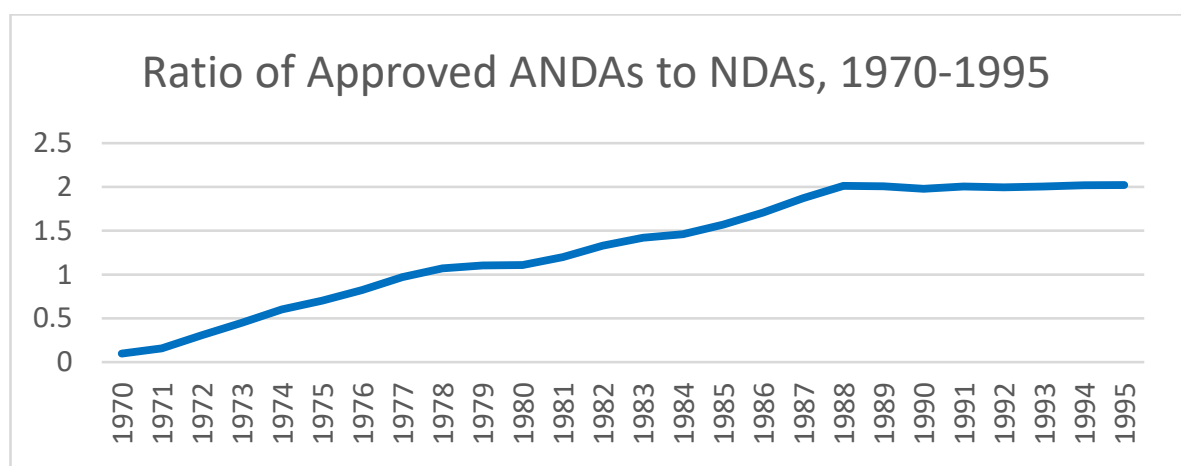

By comparison, by March 23, 2020, a decade after the enactment of BPCIA, the FDA approved a total of 268 original biologics and 26 applications for follow-on products, ${ }^{37}$ a ratio of about 0.1 follow-on products per 1 original product, or 1 follow-on product per 10 original products. The trend of ratios of the total number of approved biosimilars ("ABLA"s) to original biologics ("BLA"s) over time may be observed in the following chart:

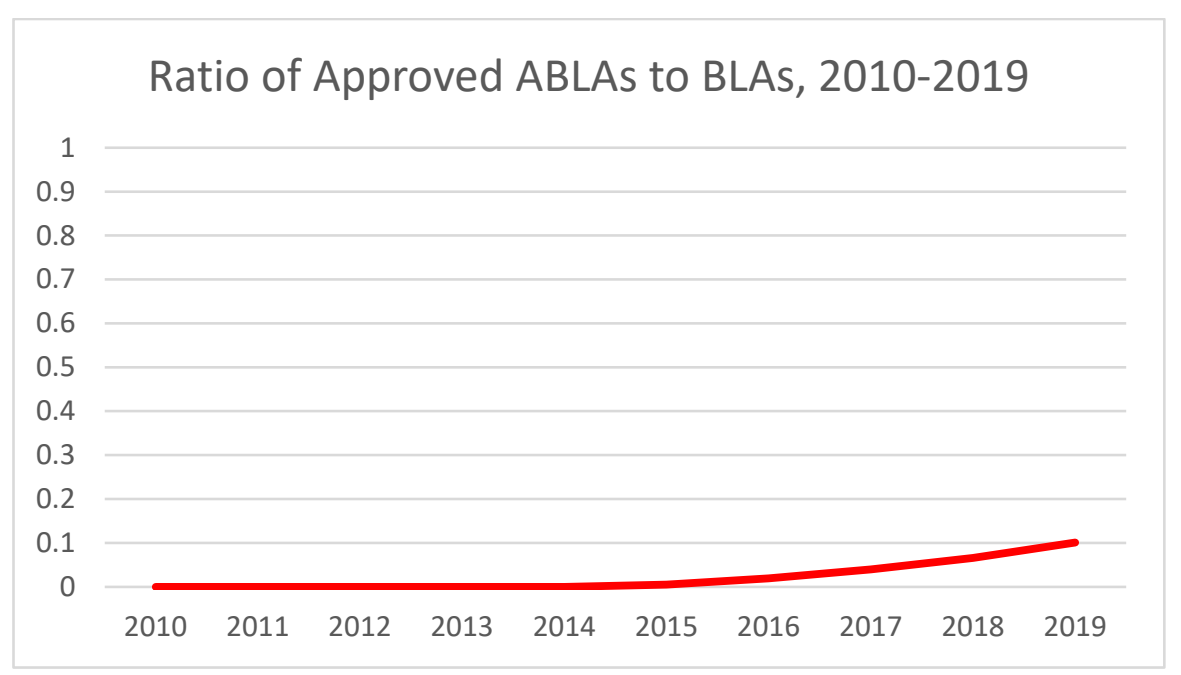

A comparison of the ratios and trends of approvals of follow-on products per original products over time is illustrated in the chart

37. See Purple Book: Database of Licensed Biological Products, U.S. FooD \& DRUG ADMIN., https://www.fda.gov/media/89426/download (last accessed June 27, 2020) [https://perma.cc/YB78-P7EK]. 
below with "year 0" designated as the year of enactment of legislation formalizing the process of approval of follow-on products-HatchWaxman Act for small-molecule drugs and BPCIA for biologics, respectively:

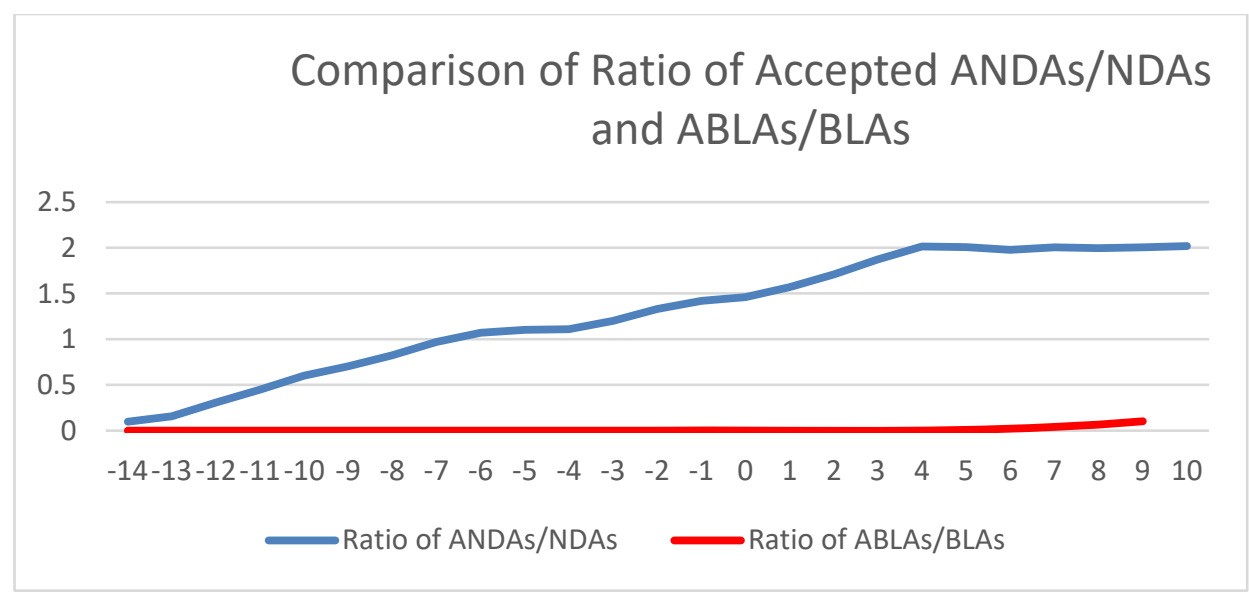

Examination of these trends reveals, again, a significant underperformance of BPCIA compared to the approval of generic drugs both before and after the enactment of the Hatch-Waxman Act. The comparative underperformance of BPCIA can be attributed, at least in part, to the fact that biologics are typically covered by more patents than a typical small-molecule drug product, are more difficult to imitate, and that the commercial and regulatory realities of small-molecule drugs and biologics are different. Still, if drafters of the BPCIA expected it to function like the Hatch-Waxman Act, then these numbers show that it is failing to do so. In comparing the performance of BPCIA to the track record of approval of follow-on small-molecule drugs, it is also important to remember that products approved under an ANDA are generic versions of the original product and, thus, automatically substitutable with the original product. Biosimilars, on the other hand-at least the ones that have been approved to date - are not automatically substitutable with the original, reference product and are, thus, inferior as potential instigators of competition and price drops in their respective drug markets, which further contributes to the conclusion that BPCIA fails to achieve its goals. 
Furthermore, experience from the area of small-molecule drugs shows that significant price drops of over $70 \%$ typically require 4 or more different competitors in the same product market. ${ }^{38}$ By April 24,1980 , there were 96 original small-molecule drug products with 4 or more approved follow-on versions; by September 24, 1984, there were 142; by September 24, 1994, there were 292. ${ }^{39}$ In comparison, by March 2020, there was only 1 original biologic - Genentech's Herceptin - with 4 follow-on versions available on the market. ${ }^{40}$ None of these 4 follow-on products are interchangeable with the original product, and the price savings in these products range between $10 \%$ $27 \%$ as compared with the original product. $^{41}$

To recap, these numbers show that ten years after the enactment of BPCIA the levels of competition (and price drops) in biologics markets are nowhere near the levels seen a decade after the FDA began approving follow-on versions of original small-molecule drug products before the enactment of the Hatch-Waxman Act. They are light-years away from the levels of competition seen ten years after the enactment of the Hatch-Waxman Act.

\section{REASONS FOR BPCIA'S POOR TRACK RECORD}

There are many causes for BPCIA's poor track record and, more generally, the ongoing lack of significant price competition in biologics markets. ${ }^{42}$ To begin with, at least some of BPCIA's

38. See New Evidence Linking Greater Generic Competition and Lower Generic Drug Prices, U.S. FOOD \& DRUG ADMIN., https:/www.fda.gov/about-fda/centerdrug-evaluation-and-research-cder/generic-competition-and-drug-prices [https://perma.cc/RVM9-2375] (last visited May 13, 2020); see also Generic Competition and Drug Prices, U.S. FOOD \& DRUG ADMIN., https://wayback.archiveit.org/7993/20190423134204/https:/www.fda.gov/AboutFDA/CentersOffices/Offi ceofMedicalProductsandTobacco/CDER/ucm129385.htm [https://perma.cc/3UZJR39Y] (last visited May 13, 2020).

39. See Drugs@FDA Data Files, U.S. Food \& Drug Admin., Drugs@FDA Data Files, https:/www.fda.gov/drugs/drug-approvals-and-databases/drugsfdadata-files [https://perma.cc/LC2E-DSFR] (last visited May 31, 2020) (data includes original and supplemental approved applications). The results exclude tentatively approved applications and supplemental applications for which there was an approved original application.

40. See infra Table I.

41. See infra Table III.

42. See e.g., Preston Atteberry et al., Biologics Are Natural Monopolies (Part 1): Why Biosimilars Do Not Create Effective Competition, HeAlTH AFFAIRS BloG (Apr. 15, 2019), https://www.healthaffairs.org/do/10.1377/hblog20190405.396631 /full/ [https://perma.cc/F4US-YPFF]; Michael A. Carrier \& Carl J. Minniti III, 
disappointing track record may be attributed to its relative "belatedness" and to delays in its implementation. By the time of BPCIA's enactment in 2010, the United States was already well behind Europe in instituting a framework for approval of follow-on biologics, especially considering that discussions of follow-on biologics and creation of a Hatch-Waxman-like framework for biologics have been ongoing in the United States since the late 1990s. ${ }^{43}$ To compare, Europe has had a framework for approval of follow-on biologics in place since 2003, approved its first biosimilar application in 2006, and has approved 66 follow-on biologics since. ${ }^{44}$ And yet, it took the FDA two years after BPCIA was enacted to issue its first draft guidance on how the FDA intends to evaluate

Biologics: The New Antitrust Frontier, 2018 U. ILL. L. REV. 1, 67-68 (2018); Heled, supra note 5 , at 135 .

43. See Krista Hessler Carver, Jeffrey Elikan, \& Erika Lietzan, An Unofficial Legislative History of the Biologics Price Competition and Innovation Act of 2009, 65 FOOD \& DRUG L.J. 671, 685-86 (2010).

44. See Medicines, EUROPEAn MEDICINES AGENCY, https://www.ema.europa.eu /en/medicines/field_ema_web_categories\%253Aname_field/Human/ema_group_ty pes/ema_medicine/field_ema_med_status/authorised36/ema_medicine_types/fiēd _ema_mēd_biosimilar/sēearch_api_aggregation_ema_medicine_types/field_ema_m ed_biosimitar [https://perma.cc/7ȲB3-TWM4] (noting two more applications were refused and, of the 66 approved products, 9 were withdrawn).

Notably, the first biosimilar approved in by the EMA was also approved in the United States that same year, albeit not as a biosimilar but rather as a drug. See Jonathan Darrow, The Rise of Biosimilars: Success of the BPCIA? (Part II), BILL OF HEALTH BLOG (Feb. 3, 2020), https://blog.petrieflom.law.harvard.edu/2020/02/03/ the-rise-of-biosimilars-success-of-the-bpcia-part-ii/ [https://perma.cc/5TFS-YGD4] (discussing the approval of somatropin (Omnitrope) in both Europe and the United States in 2006.

The comparison to Europe is only helpful with respect to the track record of follow-on product approvals to show the FDA's relative delay as compared with the EMA. The comparison to Europe becomes less helpful, however, perhaps even meaningless, when it comes to levels of competition in biologics markets and resultant price drops. This is because of two main reasons. First, virtually all European Union (EU) member states have implemented measures to control the price of biologics and do not rely on competition as the sole means of increasing access to biologics. Second, unlike the United States, Europe does not have a central framework for approval of biologics as interchangeable with each other and the substitution of original biologics with their follow-on versions is subject to specific arrangements within each of the EU member states. See, e.g., David J. Gross et al., International Pharmaceutical Spending Controls: France, Germany, Sweden, and the United Kingdom, HEALTH CARE FIN. REV. (1994), https://www.ncbi.nlm.nih.gov/pmc/articles/PMC4193451/ [https://perma.cc/DZN 9-8J2J]; Pugatch Consilium, Towards a Sustainable European Market for OffPatent Biologics, at 7, 19-21 (2019), https://www.efpia.eu/media/412909/towardsa-sustainable-european-market-for-off-patent-biologics-pugatch-consilium.pdf [https://perma.cc/B8UD-KRYZ]. 
applications for follow-on biologics and another three years to issue the final guidance. ${ }^{45}$ By that point, in April 2015, Europe had already been approving follow-on biologics for marketing for nine years and had granted approval to 21 follow-on biologic applications (with one more application refused). ${ }^{46}$ The FDA's relative delay is even more disappointing in light of the establishment in June 2011 of a collaboration between the FDA and the European Medicines Agency whose purpose has been "the alignment on scientific approaches to the evaluation of biosimilar medicines in order to increase convergence, so that data developed for one regulatory authority could be accepted to another regulatory authority." 47

But the most crucial delay has been in the implementation of BPCIA's most important part: the creation of a pathway for approval of interchangeable biosimilars. ${ }^{48}$ As the Hatch-Waxman experience has shown, a critical component of increasing access to pharmaceuticals is the automatic substitution of original products with

45. See, respectively, FDA, Guidance for Industry, Scientific Considerations in Demonstrating Biosimilarity to a Reference Product (Feb. 2012), file://C:/Users/yaniv/AppData/Local/Temp/FDA-2011-D-0605-0002.pdf; FDA, Scientific Considerations in Demonstrating Biosimilarity to a Reference Product, Guidance for Industry (Apr. 2015), file://C:/Users/yaniv/AppData/Local/Temp/Scientific_Considerations_in_Demons trating_Biosimilarity_to_a_Reference_Product_Guidance_for_Industr.pdf.

46. See Médicines, $\overline{\text { EUROPEAN }} \overline{\text { MEDICINES AGENCY, }}$ https://www.ema.europa.eu/en/medicines/field_ema_web_categories\%253Aname_ field/Human/ema_group_types/ema_medicine/field_ema_med_status/authorised36/ema_medicine types/field_ema_med biosimilar/search_api $\bar{i}$ aggregation ema medicine_types/fièld_ema_mèd_biosimiTar [https://perma.cc/7YB3-TWM $\overline{4}$ ] (showing the relative tardiness of the United States compared to Europe). Europe, however, is not a good basis for comparison of price competition in biologics because virtually all European countries employ one form or another of government control over the price of pharmaceuticals, including biologics.

47. See EMA and FDA to Collaborate on Biosimilars, GENERICS AND BIOSIMILARS INITIATIVE (July 1, 2011), http://www.gabionline.net/Biosimilars/News/EMA-and-FDA-to-collaborate-on-

biosimilars [https://perma.cc/E66E-AXFD]; Cluster Activities, EUROPEAN MEDICINES AGENCY, https://www.ema.europa.eu/en/partnersnetworks/international-activities/cluster-activities\#biosimilars-section

[https://perma.cc/6FU2-VJRX] (last accessed July 1, 2020).

48. Considerations in Demonstrating Interchangeability with a Reference Product Guidance for Industry, U.S. FOOD \& DRUG ADMIN, 1 (May 2019), https://www.fda.gov/media/124907/download [https://perma.cc/VEB7-5SU4]; Once approved as interchangeable, a biosimilar product, by definition, "may be substituted for the reference product without the intervention of the health care provider who prescribed the reference product." 42 U.S.C. $\S \S 262(\mathrm{i})(3),(\mathrm{k})(2)(\mathrm{B})$, $(\mathrm{k})(3)(\mathrm{A})(\mathrm{ii})$, and $(\mathrm{k})(4)$. 
their cheaper follow-on versions. ${ }^{49}$ Indeed, entry of mere alternative pharmaceutical products (which are not automatically substitutable, a.k.a. "me-too" drugs ${ }^{50}$ ) typically leads only to modest price drops, if any. ${ }^{51}$ Without automatic substitution, competition from noninterchangeable biosimilars has not and is unlikely to result in significant price competition. ${ }^{52}$ Yet it took the FDA more than nine years after the enactment of BPCIA to issue its guidance on how the FDA intends to evaluate interchangeability of follow-on biologics. ${ }^{53}$

49. To be sure, automatic substitution is a necessary but not sufficient condition. To achieve significant price drops of over $70 \%$, it is necessary that there be more than just 2-3 alternatives in any given product market. See New Evidence Linking Greater Generic Competition and Lower Generic Drug Prices supra note 21.

50. U.S. Cong., Office of Tech. Assessment, Pharmaceutical R\&D: COSTS, Risks AND REWARDS, OTA-H-522, at 46 (1993). ("[M]e-too drugs are introduced after the pioneer and are similar but not identical to pioneer compounds ... Many me-too drugs are developed through deliberate imitation of the pioneer compound and have a shorter and more certain discovery period. ... The pursuit of "me-too" drugs is an attempt by rival firms to shave off part of the monopoly profits enjoyed by the maker of the pioneer drug in a therapeutic class").

51. See Aidan Hollis, Me Too Drugs: Is There a Problem?, (2004), https://www.who.int/intellectualproperty/topics/ip/Me-tooDrugs_Hollis1.pdf?ua=1 [https://perma.cc/ZY7M-4ASQ] ("Me-too drugs very frequently not only fail to increase price competition but may even lead to price increases").

52. While there are a few notable exceptions, experience in both Europe and the United States thus far indicates that entry of non-interchangeable biosimilars only leads to price drops of about 5\%-35\%. See infra Table III Emerging Health Care Issues: Follow-On Biologic Drug Competition, FEDERAL TRADE COMMISSION (2009), https://www.ftc.gov/sites/default/files/documents/reports/emerging-healthcare-issues-follow-biologic-drug-competition-federal-trade-commission-

report/p083901biologicsreport.pdf (last visited June 3, 2020) [https://perma.cc/675V-V7KP]; Francis Megerlin, et al., Biosimilars and the European Experience: Implications for the United States, 32 HEALTH AFFAIRS 1803, 1803 (2013). But see, e.g., Eric Sagonowsky, AbbVie offers up 80\% Humira Discount in EU Tender Market to Hold Off Biosimilars: Report, FIERCEPHARMA (Oct. 31, 2018), https://www.fiercepharma.com/pharma/abbvie-offers-up-80humira-discount-eu-tender-market-to-hold-off-biosims-report [https://perma.cc/ 8KFT-4E66]. However, without interchangeability such price drops are highly unlikely in the United States, which - unlike European countries (and virtually all other countries) - has no means for controlling the price of pharmaceuticals and relies exclusively on competition to lower the cost of biologics in hopes that market mechanisms would, eventually, result in increased access. Examples of significant price drops in certain biologics market products in specific European countries are therefore not instructive for the United States.

53. Considerations in Demonstrating Interchangeability with a Reference Product Guidance for Industry, U.S. FOOD \& DRUG ADMIN., (May 2019), https://www.fda.gov/media/124907/download [https://perma.cc/R2WG-HNUP]. To be fair, in coming up with its interchangeability guidance, since no other country - including Europe-has created a way of establishing interchangeability, the FDA had to create a completely new framework without being able to learn 
Notably, recognizing the glacial pace of entry of competition into biologics markets, in July 2018, the FDA announced a Biosimilars Action Plan, whose stated goal is to increase patient access to biologics and which includes measures and initiatives to that effect. ${ }^{54}$ As mandated under BPCIA, ${ }^{55}$ the FDA has also taken steps to increase competition in older biologics (e.g., insulin and human growth hormone, which have been previously approved as drugs) by "deeming" them subject to follow-on competition under BPCIA as of March 2020. ${ }^{56}$ The effects of these measures on competition in biologics markets are yet to be seen. ${ }^{57}$

A second likely reason for BPCIA's poor track record is that, to begin with, making follow-on versions of biologics is a much more complex, expensive, and risky (but apparently not more time-consuming ${ }^{58}$ ) business than making follow-on versions of small-

(much) from experience in other jurisdictions.

54. Biosimilars Action Plan: Balancing Innovation and Competition, U.S. FoOD \& DRUG ADMIN., (Jul. 2018), https://www.fda.gov/media/114574/download [https://perma.cc/2JZH-9U3W].

55. Biologics Price Competition and Innovation Act of 2009, 42 U.S.C. $\S 262$ note (2006, Supp. IV 2010) (Conforming Amendments Under The Federal Food, Drug, And Cosmetic Act) ("An approved application for a biological product under section 505 of the Federal Food, Drug, and Cosmetic Act . . . shall be deemed to be a license for the biological product under [BPCIA] on the date that is 10 years after the date of enactment of this Act.").

56. See "Deemed to be a License" Provision of the BPCI Act, U.S. FoOD \& DRUG ADMIN., https://www.fda.gov/drugs/guidance-compliance-regulatoryinformation/deemed-be-license-provision-bpci-act (last accessed May 16, 2020) [https://perma.cc/6GJZ-7LB4]; List of Approved NDAs for Biological Products that were Deemed to be BLAs on March 23, 2020, U.S. FoOD \& DRUG ADMIN. (2020), https://www.fda.gov/media/119229/download [https://perma.cc/C8B2-3JK5].

57. Several commentators, including former FDA Commissioner, Scott Gottlieb, and the undersigned, have expressed skepticism regarding the FDA's ability to lower biologics prices. See, e.g., Simone A. Rose and Tracea Rice, The Biosimilar Action Plan: An Effective Mechanism for Balancing Biologic Innovation and Competition in the United States?, MCGEORGE LAW REVIEW (forthcoming 2020) (expressing skepticism about the FDA's Biosimilar Action Plan ability to curb anticompetitive behaviors that negatively impact access to biologics); Sue Sutter, Interchangeability Won't Solve US Biosimilar Market's Woes, FDA's Gottlieb Says, PINK SHEET, Jul. 18 , 2018 , https://pink.pharmaintelligence.informa.com/PS123525/Interchangeability-WontSolve-US-Biosimilar-Markets-Woes-FDAs-Gottlieb-Says; Sue Sutter, Biosimilar Switching Studies May Not Be Worth Effort For US Interchangeability, Sponsors Say, PINK SHEET, Nov. 2019, https://pink.pharmaintelligence.informa.com/PS141151/Biosimilar-Switching-

Studies-May-Not-Be-Worth-Effort-For-US-Interchangeability-Sponsors-Say.

58. See Reed F. Beall et al., Pre-Market Development Times for Biologic Versus Small-Molecule Drugs, 37 NATURE BiOTECH 708, 709 (2019). 
molecule drugs. ${ }^{59}$ As a result of this reality, only a handful companies have the technical capabilities and financial means necessary to develop and commercialize follow-on biologics, leading to highly concentrated (and cartel-prone) product markets.

Other reasons for BPCIA's poor track record can be traced back to the original biologics industry's successful efforts to block, delay, and undermine competition in biologics markets by any means at their disposal. As described more fully elsewhere, these successes include convincing the FDA and Congress to accept and uphold the industry's view that regulatory filings submitted to the FDA are proprietary and confidential; ${ }^{60}$ enacting laws in virtually all states and United States territories that make the substitution of original biologics with follow-on versions onerous and cumbersome; ${ }^{61}$ filing lawsuits - sometimes multiple - against virtually any attempt to approve and launch follow-on biologics, ${ }^{62}$ and amassing vast patent portfolios with the explicit goal of deterring potential competitors from attempting to develop and launch follow-on versions of original biologics. ${ }^{63}$

59. See, e.g., Jonathan Darrow, The Rise of Biosimilars: Success of the BPCIA? (Part I), BILL OF HEALTH BLOG (Jan. 31, 2020), https://blog.petrieflom.law.harvard.edu/2020/01/31/the-rise-of-biosimilars-successof-the-bpcia/ [https://perma.cc/E8RS-FR56] (citing also differences in patient population sizes and drug manufacturing, storage, and transportation costs).

60. See Heled, supra note 5, at 119; Yaniv Heled, The Case for Disclosure of Biologics Manufacturing Information, 47 J. L. MED. ETHICS 54, 56 (2019).

61. See Heled, supra note 5, at 125-128 (2018).

62. Id. at 128-133; see also Joshua Whitehill, BPCIA Litigations, BIG Molecule WATCH Blog (last visited June 1, 2020), https://www.bigmoleculewatch.com/bpcia-patent-litigations/

[https://perma.cc/HSW8-GVJP] (listing 28 different litigation cases.)

63. See, e.g., Stanton R. Mehr, Can the FTC Clear a Path to Biosimilar Access Through the Patent Thicket?, BIOSIMILAR DEVElOPMENT (Jun. 4, 2019), https://www.biosimilardevelopment.com/doc/can-the-ftc-clear-a-path-for-

biosimilar-access-through-the-patent-thicket-0001 [https://perma.cc/E2M8XDZT]; Andrew Pollack, Makers of Humira and Enbrel Using New Drug Patents to Delay Generic Versions, N.Y. TIMES (Jul. 15, 2016) (quoting an AbbVie executive saying "[a]ny company seeking to market a biosimilar version of Humira will have to contend with this extensive patent estate, which AbbVie intends to enforce vigorously"); Cynthia Koons, This Shield of Patents Protects the World's Best-Selling Drug, BlOOMBERG BusINESSWEEK (Sept. 7, 2017, 5:00 AM), https:/www.bloomberg.com/news/articles/2017-09-07/this-shield-of-patentsprotects-the-world-s-best-selling-drug [https://perma.cc/3PJ9-QWSW]; Biosimilars Council, FAILURE TO LAUNCH: BARRIERs to BIOSIMILAR MARKET AdOPTION 1, 4 (2019), https://www.biosimilarscouncil.org/wp-content/uploads/2019/09/AAMBiosimilars-Council-Failure-to-Launch-2-web.pdf [https://perma.cc/2EWA- 
Another possible contributor to BPCIA's failure to result in significant price drops is the lack of adoption of biosimilars by patients, prescribers, and payors, ${ }^{64}$ which may also be partially attributable to original biologics developers' efforts to undermine competition in biologics markets. ${ }^{65}$ This lack of adoption, in and of itself, might be a result of some of the underlying realities of biologics markets (e.g., insufficient cost savings to encourage switching to the biosimilar, regulatory hassle involved in switching, lack of clear clinical finding(s) of substitutability, etc.), and such lack of adoption is sure to make the development and marketing of follow-on biologics an even less attractive prospect.

Last but not least, BPCIA's failure to instill significant levels of competition into biologics markets is due to the act itself. Although BPCIA drafters and proponents have sought to portray it as a compromise between the interests of original and follow-on biologics developers, the reality is that BPCIA has always been highly favorable to the original biologics developers who forcefully promoted it. ${ }^{66}$ Most critically, unlike the Hatch-Waxman Act, BPCIA does not make the development and approval of follow-on biologics sufficiently cheap for follow-on product developers, making it difficult for biosimilar

KQ2U].

64. See, e.g., Richard G. Frank, Friction in the Path to Use of Biosimilar Drugs, 378 New Eng. J. MeD. 791, 791 (2018); Ed Silverman, Biosimilars Got the Cold Shoulder from Health Plans when it Came to Preferred Coverage, STAT+ (May 20, 2020), https://www.statnews.com/pharmalot/2020/05/20/biosimilars-biologicshealth-coverage-drug-prices/ [https://perma.cc/M3R2-2XNB]; Biosimilars Council, FAILURE TO LAUNCH: BARRIERS TO BIOSIMILAR MARKET ADOPTION 1, 4 (2019), https://www.biosimilarscouncil.org/wp-content/uploads/2019/09/AAM-

Biosimilars-Council-Failure-to-Launch-2-web.pdf [https://perma.cc/2EWAKQ2U].

65. See, e.g., Citizen Pet., PFIZER, INC. (Aug. 22, 2018), https://www.regulations.gov/document?D=FDA-2018-P-3281-0001

[https://perma.cc/76RQ-ES4M] (decrying "certain patient-directed materials and social media disseminated by reference product sponsors omit[ing] or misstat[ing] key aspects of the definition of a biosimilar" and mischaracterizing the concepts of interchangeability and switching, and more); see also Promotional Labeling and Advertising Considerations for Prescription Biological Reference and Biosimilar Products Questions and Answers, Draft Guidance for Industry, U.S. FOOD AND DRUG ADMIN. (2020), https://www.fda.gov/media/134862/download [https://perma.cc/62RS-2X4E].

66. See Heled, supra note 5, at 115-19. One possible way of achieving this goal would be to make original biologics manufacturing information available to followon product developers, which would save them the significant resources necessary to recreate their own version of the original biologic such that it is sufficiently similar to be deemed "biosimilar" and/or interchangeable. Id. 
developers to sell their products at significant discounts compared to the original product. ${ }^{67}$

\section{CONCLUSION}

Ten years after the enactment of BPCIA, the picture of competition in biologics entails a meager dozen actors wrestling over market share with their 16 me-too versions of 7 original reference products with little price competition and small to minimal savings for payors and patient-consumers. Competition in biologics at this time does not even begin to resemble the extent, savings, or kind of competition seen in drug markets even before the enactment of the Hatch-Waxman Act, let alone a decade after it was signed into law.

The big winners in the current situation are pharma companies - both original and follow-on - that share in the bounty of increasing market demand for biologics and persistently high prices with minimal price erosion due to the launch of a few noninterchangeable biosimilars per original product. At the same time, BPCIA has brought very little change to patient-consumers who continue to have few prescribing options for which they pay nearly the same price as they would for the original product. For payors, BPCIA provides very little salve to an ever-growing expenditure on biologics. For doctors and pharmacists, the lack of automatic substitution and increased administrative burden of using biosimilars mostly embodies a headache.

If lowering the price of biologics is the goal and competition (rather than direct price regulation) is the means by which we seek to achieve that goal, then we ought to surmise that our primary instrument for lowering the price of biologics is deeply flawed and needs to be fixed. Setting aside the FDA's partial responsibility for the delay in the implementation of BPCIA, there is very little that the FDA could do within the confines of its current powers to improve access to biologics. As I have argued elsewhere, it is highly doubtful that the measures the FDA is taking would be enough to lead to significant price competition in biologics markets. ${ }^{68}$ Remedying the current state of competition in biologics markets would require changing the paradigm of approval of follow-on biologics. This, however, can only

67. See Heled, supra note 60 , at 56-58.

68. See Heled, supra note 60, at 55; see also Rose \& Rice, supra note 57, at 1. 
be done in primary legislation, making significant changes to BPCIA itself. But to do so, we must first recognize that BPCIA in its current form is not and, in all likelihood, will not bring significant price competition to United States biologics markets.

While some still argue that BPCIA has not yet reached its full potential of increasing access to biologics ${ }^{69}$ it is imperative that we ask: if BPCIA's current track record is (still) not enough to convince us that it has failed to achieve its goal of significantly increasing access to biologics in the United States, what more would it take to reach such a conclusion, and how much longer should policymakers wait before we can surmise that? In answering this question, we ought to remember that the real goal behind the efforts to increase competition in biologics markets has never been to merely instigate some competition, mostly over market share, in a few highly lucrative product markets. Rather, it is to bring significant price drops that increase access to biologics and ultimately improve public health.

69. See Jonathan Darrow, The Rise of Biosimilars: Success of the BPCIA? (Part III), BILL OF HEALTH BLOG (Feb. 4, 2020), https://blog.petrieflom.law.harvard.edu/2020/02/04/the-rise-of-biosimilars-successof-the-bpcia-part-iii/ [https://perma.cc/C4W4-LCJ5]. 


\section{APPENDIX A}

TABLE I

\begin{tabular}{|c|c|c|c|c|c|c|c|}
\hline $\begin{array}{l}\text { Product } \\
\text { Name }\end{array}$ & $\begin{array}{c}\text { Biosimilar } \\
\text { Manufacturer }\end{array}$ & $\begin{array}{c}\text { Active } \\
\text { Ingredient }\end{array}$ & $\begin{array}{c}\text { Reference } \\
\text { product }\end{array}$ & $\begin{array}{c}\text { Reference } \\
\text { Manufacturer }\end{array}$ & $\begin{array}{c}\text { Date of } \\
\text { Approval }\end{array}$ & $\begin{array}{c}\text { Available } \\
\text { as of } \\
3 / 23 / 2020 ?\end{array}$ & $\begin{array}{l}\text { Availability } \\
\text { on U.S. } \\
\text { Market }^{70}\end{array}$ \\
\hline Hyrimoz & Sandoz & $\begin{array}{l}\text { adalimumab- } \\
\text { adaz }\end{array}$ & Humira & AbbVie & $10 / 30 / 2018$ & No & \\
\hline Cyltezo & $\begin{array}{l}\text { Boehringer } \\
\text { Ingelheim }\end{array}$ & $\begin{array}{l}\text { adalimumab- } \\
\text { adbm }\end{array}$ & Humira & AbbVie & $8 / 25 / 2017$ & No & \\
\hline Abrilada & Pfizer & $\begin{array}{c}\text { adalimumab- } \\
\text { afzb }\end{array}$ & Humira & AbbVie & $11 / 15 / 2019$ & No & \\
\hline Amjevita & Amgen & $\begin{array}{l}\text { adalimumab- } \\
\text { atto }\end{array}$ & Humira & AbbVie & $9 / 23 / 2016$ & No & \\
\hline Hadlima & $\begin{array}{l}\text { Samsung } \\
\text { Bioepis }\end{array}$ & $\begin{array}{l}\text { adalimumab- } \\
\text { bwwd }\end{array}$ & Humira & AbbVie & 7/23/2019 & No & \\
\hline Mvasi & Amgen & $\begin{array}{c}\text { bevacizumab- } \\
\text { awwb }\end{array}$ & Avastin & Genentech & $9 / 14 / 2017$ & Yes & $7 / 18 / 2019$ \\
\hline Zirabev & Pfizer & $\begin{array}{l}\text { bevacizumab- } \\
\text { bvzr }\end{array}$ & Avastin & Genentech & 6/27/2019 & Yes & $1 / 13 / 2020$ \\
\hline Retacrit & Hospira/Pfizer & $\begin{array}{l}\text { epoetin alfa- } \\
\text { epbx }\end{array}$ & Epogen/Procrit & Amgen & $5 / 15 / 2018$ & Yes & $11 / 12 / 2018$ \\
\hline Erelzi & Sandoz & $\begin{array}{l}\text { etanercept- } \\
\text { szzs }\end{array}$ & Enbrel & Amgen & $8 / 30 / 2016$ & No & \\
\hline Eticovo & $\begin{array}{l}\text { Samsung } \\
\text { Bioepis }\end{array}$ & $\begin{array}{l}\text { etanercept- } \\
\text { ykro }\end{array}$ & Enbrel & Amgen & $4 / 25 / 2019$ & No & \\
\hline Nivestym & Hospira/Pfizer & filgrastim-aafi & Neupogen & Amgen & $7 / 20 / 2018$ & Yes & $10 / 1 / 2018$ \\
\hline Zarxio & Sandoz & $\begin{array}{l}\text { filgrastim- } \\
\text { sndz }\end{array}$ & Neupogen & Amgen & $3 / 6 / 2015$ & Yes & $9 / 3 / 2015$ \\
\hline Renflexis & $\begin{array}{l}\text { Samsung } \\
\text { Bioepis }\end{array}$ & $\begin{array}{l}\text { infliximab- } \\
\text { abda }\end{array}$ & Remicade & $\begin{array}{c}\text { Janssen } \\
\text { Biotech (J\&J } \\
\text { subsidiary) }\end{array}$ & $4 / 21 / 2017$ & Yes & $7 / 24 / 2017$ \\
\hline Avsola & Amgen & $\begin{array}{l}\text { infliximab- } \\
\text { axxq }\end{array}$ & Remicade & $\begin{array}{c}\text { Janssen } \\
\text { Biotech (J\&J } \\
\text { subsidiary) }\end{array}$ & $12 / 6 / 2019$ & No & \\
\hline Inflectra & Celltrion/Teva & $\begin{array}{l}\text { infliximab- } \\
\text { dyyb }\end{array}$ & Remicade & $\begin{array}{c}\text { Janssen } \\
\text { Biotech (J\&J } \\
\text { subsidiary) }\end{array}$ & $4 / 5 / 2016$ & Yes & $11 / 28 / 2016$ \\
\hline Ixifi & Pfizer & $\begin{array}{l}\text { infliximab- } \\
\text { qbtx }\end{array}$ & Remicade & $\begin{array}{c}\text { Janssen } \\
\text { Biotech (J\&J } \\
\text { subsidiary) }\end{array}$ & $12 / 13 / 2017$ & No & \\
\hline
\end{tabular}

\footnotetext{
${ }^{70}$ Various sources on file with author.
} 


\begin{tabular}{|c|c|c|c|c|c|c|c|}
\hline $\begin{array}{c}\text { Product } \\
\text { Name }\end{array}$ & $\begin{array}{c}\text { Biosimilar } \\
\text { Manufacturer }\end{array}$ & $\begin{array}{c}\text { Active } \\
\text { Ingredient }\end{array}$ & $\begin{array}{c}\text { Reference } \\
\text { product }\end{array}$ & $\begin{array}{c}\text { Reference } \\
\text { Manufacturer }\end{array}$ & $\begin{array}{c}\text { Date of } \\
\text { Approval }\end{array}$ & $\begin{array}{c}\text { Available } \\
\text { as of } \\
\mathbf{3} / 23 / 2020 ?\end{array}$ & $\begin{array}{c}\text { Availability } \\
\text { on U.S. } \\
\text { Market }\end{array}$ \\
\hline Ziextenzo & Sandoz & $\begin{array}{c}\text { pegfilgrastim- } \\
\text { bmez }\end{array}$ & Neulasta & Amgen & $11 / 4 / 2019$ & Yes & $11 / 15 / 2019$ \\
\hline Udenyca & $\begin{array}{c}\text { Coherus } \\
\text { BioSciences }\end{array}$ & $\begin{array}{c}\text { pegfilgrastim- } \\
\text { cbqv }\end{array}$ & Neulasta & Amgen & $11 / 2 / 2018$ & Yes & $1 / 3 / 2019$ \\
\hline Fulphila & Mylan GmbH & $\begin{array}{c}\text { pegfilgrastim- } \\
\text { jmdb }\end{array}$ & Neulasta & Amgen & $6 / 4 / 2018$ & Yes & $7 / 26 / 2018$ \\
\hline Truxima & Celltrion/Teva & $\begin{array}{c}\text { rituximab- } \\
\text { abbs }\end{array}$ & Rituxan & Genentech & $11 / 28 / 2018$ & Yes & $11 / 7 / 2019$ \\
\hline Ruxience & Pfizer & $\begin{array}{c}\text { rituximab- } \\
\text { pvvr }\end{array}$ & Rituxan & Genentech & $7 / 23 / 2019$ & Yes & $1 / 23 / 2020$ \\
\hline Kanjinti & Amgen & $\begin{array}{c}\text { trastuzumab- } \\
\text { anns }\end{array}$ & Herceptin & Genentech & $6 / 13 / 2019$ & Yes & $7 / 18 / 2019$ \\
\hline Ogivri & Mylan GmbH & $\begin{array}{c}\text { trastuzumab- } \\
\text { dkst }\end{array}$ & Herceptin & Genentech & $12 / 1 / 2017$ & Yes & $12 / 2 / 2019$ \\
\hline Ontruzant & Samsung & trastuzumab- & Herceptin & Genentech & $1 / 18 / 2019$ & No & $4 / 15 / 2020$ \\
\hline Herzuma & Celltrion/Teva & $\begin{array}{c}\text { trastuzumab- } \\
\text { pkrb }\end{array}$ & Herceptin & Genentech & $12 / 14 / 2018$ & Yes & $3 / 16 / 2020$ \\
\hline Trazimera & Pfizer & $\begin{array}{c}\text { trastuzumab- } \\
\text { qyyp }\end{array}$ & Herceptin & Genentech & $3 / 11 / 2019$ & Yes & $2 / 19 / 2020$ \\
\hline
\end{tabular}

${ }^{71}$ Various sources on file with author. 


\section{TABLE II ${ }^{72}$}

\begin{tabular}{|c|c|c|c|c|}
\hline $\begin{array}{l}\text { Product } \\
\text { Name }\end{array}$ & $\begin{array}{l}\text { Average Price on } \\
\text { Drugs.com }\end{array}$ & $\begin{array}{l}\text { Average Price } \\
\text { on } \\
\text { GoodRx.com }\end{array}$ & $\begin{array}{l}\text { Average Price of Reference } \\
\text { Product on Drugs.com }\end{array}$ & $\begin{array}{l}\text { Average Price of } \\
\text { Reference } \\
\text { Product on } \\
\text { GoodRx.com }\end{array}$ \\
\hline Hyrimoz & & & $\begin{array}{l}\text { Humira subcutaneous kit (10 } \\
\mathrm{mg} / 0.1 \mathrm{ml} \text { ) is around } \$ 5,810.97 \text { for } \\
\text { a supply of } 2\end{array}$ & $\begin{array}{c}\$ 8,542 \text { for } 1 \text { carton } \\
(2 \text { pens) of Humira } \\
40 \mathrm{mg} / 0.4 \mathrm{ml}\end{array}$ \\
\hline Cyltezo & & & $\begin{array}{l}\text { Humira subcutaneous kit (10 } \\
\mathrm{mg} / 0.1 \mathrm{ml} \text { ) is around } \$ 5,810.97 \text { for } \\
\text { a supply of } 2\end{array}$ & $\begin{array}{l}\$ 8,542 \text { for } 1 \text { carton } \\
(2 \text { pens) of Humira } \\
40 \mathrm{mg} / 0.4 \mathrm{~m}\end{array}$ \\
\hline Abrilada & & & $\begin{array}{l}\text { Humira subcutaneous kit }(10 \\
\mathrm{mg} / 0.1 \mathrm{ml} \text { ) is around } \$ 5,810.97 \text { for } \\
\text { a supply of } 2\end{array}$ & $\begin{array}{l}\$ 8,542 \text { for } 1 \text { carton } \\
(2 \text { pens) of Humira } \\
40 \mathrm{mg} / 0.4 \mathrm{ml}\end{array}$ \\
\hline Amjevita & & & $\begin{array}{l}\text { Humira subcutaneous kit ( } 10 \\
\mathrm{mg} / 0.1 \mathrm{ml} \text { ) is around } \$ 5,810.97 \text { for } \\
\text { a supply of } 2\end{array}$ & $\begin{array}{l}\$ 8,542 \text { for } 1 \text { carton } \\
(2 \text { pens) of Humira } \\
40 \mathrm{mg} / 0.4 \mathrm{ml}\end{array}$ \\
\hline Hadlima & & & $\begin{array}{l}\text { Humira subcutaneous kit (10 } \\
\mathrm{mg} / 0.1 \mathrm{ml} \text { ) is around } \$ 5,810.97 \text { for } \\
\text { a supply of } 2\end{array}$ & $\begin{array}{c}\$ 8,542 \text { for } 1 \text { carton } \\
(2 \text { pens) of Humira } \\
40 \mathrm{mg} / 0.4 \mathrm{ml} \\
\end{array}$ \\
\hline Mvasi & $\begin{array}{l}\$ 716.71 \text { for a supply of } 4 \\
\mathrm{ml} \text { of intravenous solution } \\
(\text { awwb } 25 \mathrm{mg} / \mathrm{ml})\end{array}$ & N/A & $\begin{array}{l}\text { Avastin intravenous solution ( } 25 \\
\mathrm{mg} / \mathrm{ml}) \text { is around } \$ 841.51 \text { for a } \\
\text { supply of } 4 \mathrm{ml}\end{array}$ & N/A \\
\hline Zirabev & N/A & N/A & $\begin{array}{c}\text { Avastin intravenous solution ( } 25 \\
\mathrm{mg} / \mathrm{ml}) \text { is around } \$ 841.51 \text { for a } \\
\text { supply of } 4 \mathrm{ml}\end{array}$ & N/A \\
\hline Retacrit & $\begin{array}{l}\text { Retacrit injectable solution } \\
\text { (epbx 2000 units/ml } \\
\text { preservative-free) is around } \\
\$ 239.81 \text { for a supply of } 10 \\
\text { ml }\end{array}$ & $\begin{array}{c}\$ 564.36 \text { for } 4 \\
\text { vials }(1 \mathrm{ml}) \text { of } \\
\text { Retacrit } 10000 \\
\text { units } / \mathrm{ml}\end{array}$ & $\begin{array}{l}\text { Epogen injectable solution ( } 2000 \\
\text { units/ml preservative-free) is } \\
\text { around } \$ 355.69 \text { for a supply of } 10 \\
\mathrm{ml}\end{array}$ & $\begin{array}{l}\$ 48.81 \text { for } 1 \text { vial } \\
(1 \mathrm{ml}) \text { of Epogen } \\
2000 \text { units } / \mathrm{ml}\end{array}$ \\
\hline Erelzi & & & $\begin{array}{l}\text { Enbrel subcutaneous kit } 25 \mathrm{mg} \text { is } \\
\text { around } \$ 2,910.22 \text { for a supply of } 4 \\
\text { kits }\end{array}$ & $\begin{array}{l}\$ 8,389.15 \text { for } 1 \\
\text { carton (4 sure } \\
\text { clicks) of Enbrel } \\
50 \mathrm{mg}\end{array}$ \\
\hline Eticovo & & & $\begin{array}{l}\text { Enbrel subcutaneous kit } 25 \mathrm{mg} \text { is } \\
\text { around } \$ 2,910.22 \text { for a supply of } 4 \\
\text { kits }\end{array}$ & $\begin{array}{l}\$ 8,389.15 \text { for } 1 \\
\text { carton (4 sure } \\
\text { clicks) of Enbrel } \\
50 \mathrm{mg} \\
\end{array}$ \\
\hline
\end{tabular}

${ }^{72}$ Data collected on May 7, 2020. All sources are on file with author. 


\begin{tabular}{|c|c|c|c|c|}
\hline $\begin{array}{l}\text { Product } \\
\text { Name }\end{array}$ & Average Price on Drugs.com & $\begin{array}{l}\text { Average Price on } \\
\text { GoodRX.com }\end{array}$ & $\begin{array}{l}\text { Average Price of Reference } \\
\text { Product on Drugs.com }\end{array}$ & $\begin{array}{l}\text { Average Price of } \\
\text { Reference } \\
\text { Product on } \\
\text { GoodRX.com }\end{array}$ \\
\hline Nivestym & $\begin{array}{c}\text { Nivestym injectable solution } \\
\text { (aafi } 300 \mathrm{mcg} / 0.5 \mathrm{ml} \text { ) is } \\
\text { around } \$ 238.14 \mathrm{for} \text { a supply of } \\
0.5 \mathrm{ml}\end{array}$ & $\begin{array}{c}\$ 2,254.90 \text { for } 5 \\
\text { syringes }(0.8 \mathrm{ml}) \text { of } \\
\text { Nivestym } 480 \mathrm{mcg}\end{array}$ & $\begin{array}{l}\text { Neupogen injectable solution } \\
(300 \mathrm{mcg} / \mathrm{ml}) \text { is around } \\
\$ 3,296.36 \text { for a supply of } 10 \mathrm{ml} \\
\text { or } \$ 357.88 \text { for } 0.5 \mathrm{ml} \text { at } \\
300 \mathrm{mcg} / 0.5 \mathrm{ml}\end{array}$ & $\begin{array}{l}\$ 2,370.92 \text { for } 5 \\
\text { syringes }(0.5 \mathrm{ml}) \\
\text { of Neupogen } \\
300 \mathrm{mcg}\end{array}$ \\
\hline Zarxio & $\begin{array}{c}\text { Zarxio injectable solution } \\
\text { (sndz } 300 \mathrm{mcg} / 0.5 \mathrm{ml} \text { ) is } \\
\text { around } \$ 295.93 \mathrm{for} \text { a supply of } \\
0.5 \mathrm{ml}\end{array}$ & $\begin{array}{l}\$ 1,652.01 \text { for } 5 \\
\text { syringes }(0.5 \mathrm{ml}) \text { of } \\
\text { Zarxio } 300 \mathrm{mcg}\end{array}$ & $\begin{array}{l}\text { Neupogen injectable solution } \\
(300 \mathrm{mcg} / \mathrm{ml}) \text { is around } \\
\$ 3,296.36 \text { for a supply of } 10 \mathrm{ml}\end{array}$ & $\begin{array}{l}\$ 2,370.92 \text { for } 5 \\
\text { syringes }(0.5 \mathrm{ml}) \\
\text { of Neupogen } \\
300 \mathrm{mcg}\end{array}$ \\
\hline Renflexis & $\begin{array}{l}\text { Renflexis intravenous powder } \\
\text { for injection abda } 100 \mathrm{mg} \text { is } \\
\text { around } \$ 796.04 \text { for a supply of } \\
1 \text { powder for injection }\end{array}$ & $\begin{array}{l}\$ 4,520.54 \text { for } 5 \\
\text { vials of Renflexis } \\
100 \mathrm{mg}\end{array}$ & $\begin{array}{l}\text { Remicade intravenous powder } \\
\text { for injection } 100 \text { mg is around } \\
\$ 1,228.70 \text { for a supply of } 1 \\
\text { powder for injection }\end{array}$ & $\begin{array}{l}\$ 5,736.81 \text { for } 4 \\
\text { vials of Remicade } \\
100 \mathrm{mg}\end{array}$ \\
\hline Avsola & & & $\begin{array}{c}\text { Remicade intravenous powder } \\
\text { for injection } 100 \mathrm{mg} \text { is around } \\
\$ 1,228.70 \text { for a supply of } 1 \\
\text { powder for injection }\end{array}$ & $\begin{array}{l}\$ 5,736.81 \text { for } 4 \\
\text { vials of Remicade } \\
100 \mathrm{mg}\end{array}$ \\
\hline Inflectra & $\begin{array}{l}\text { Inflectra intravenous powder } \\
\text { for injection dyyb } 100 \mathrm{mg} \text { is } \\
\text { around } \$ 997.42 \text { for a supply of } \\
1 \text { powder for injection }\end{array}$ & $\begin{array}{l}\$ 4,554.50 \text { for } 4 \\
\text { vials of Inflectra } \\
100 \mathrm{mg}\end{array}$ & $\begin{array}{l}\text { Remicade intravenous powder } \\
\text { for injection } 100 \text { mg is around } \\
\$ 1,228.70 \text { for a supply of } 1 \\
\text { powder for injection }\end{array}$ & $\begin{array}{l}\$ 5,736.81 \text { for } 4 \\
\text { vials of Remicade } \\
100 \mathrm{mg}\end{array}$ \\
\hline Ixifi & & & $\begin{array}{l}\text { Remicade intravenous powder } \\
\text { for injection } 100 \mathrm{mg} \text { is around } \\
\$ 1,228.70 \text { for a supply of } 1 \\
\text { powder for injection }\end{array}$ & $\begin{array}{l}\$ 5,736.81 \text { for } 4 \\
\text { vials of Remicade } \\
100 \mathrm{mg}\end{array}$ \\
\hline Ziextenzo & $\begin{array}{c}\text { Ziextenzo subcutaneous } \\
\text { solution (bmez } 6 \mathrm{mg} / 0.6 \mathrm{ml}) \text { is } \\
\text { around } \$ 4,107.76 \mathrm{for} \text { a supply } \\
\text { of } 0.6 \mathrm{ml}\end{array}$ & N/A & $\begin{array}{l}\text { Neulasta subcutaneous solution } \\
(6 \mathrm{mg} / 0.6 \mathrm{ml}) \text { is around } \\
\$ 6,514.72 \text { for a supply of } 0.6 \mathrm{ml}\end{array}$ & $\begin{array}{l}\$ 8,402.23 \text { for } 1 \\
\text { syringe of } \\
\text { Neulasta } \\
(6 \mathrm{mg} / 0.6 \mathrm{ml})\end{array}$ \\
\hline Udenyca & $\begin{array}{l}\text { Udenyca subcutaneous } \\
\text { solution (cbqv } 6 \mathrm{mg} / 0.6 \mathrm{ml}) \text { is } \\
\text { around } \$ 4,368.20 \text { for a supply } \\
\text { of } 0.6 \mathrm{ml}\end{array}$ & $\begin{array}{c}\$ 5,462.74 \text { for } 1 \\
\text { syringe of Udenyca } \\
\quad(6 \mathrm{mg} / 0.6 \mathrm{ml})\end{array}$ & $\begin{array}{l}\text { Neulasta subcutaneous solution } \\
\quad(6 \mathrm{mg} / 0.6 \mathrm{ml}) \text { is around } \\
\$ 6,514.72 \text { for a supply of } 0.6 \mathrm{ml}\end{array}$ & $\begin{array}{l}\$ 8,402.23 \text { for } 1 \\
\text { syringe of } \\
\text { Neulasta } \\
(6 \mathrm{mg} / 0.6 \mathrm{ml})\end{array}$ \\
\hline Fulphila & $\begin{array}{l}\text { Fulphila subcutaneous } \\
\text { solution (jmdb } 6 \mathrm{mg} / 0.6 \mathrm{ml} \text { ) is } \\
\text { around } \$ 4,368.20 \text { for a supply } \\
\text { of } 0.6 \mathrm{ml}\end{array}$ & $\begin{array}{l}\$ 5,532.26 \text { for } 1 \\
\text { syringe of Fulphilia } \\
\quad(6 \mathrm{mg} / 0.6 \mathrm{ml})\end{array}$ & $\begin{array}{l}\text { Neulasta subcutaneous solution } \\
\quad(6 \mathrm{mg} / 0.6 \mathrm{ml}) \text { is around } \\
\$ 6,514.72 \text { for a supply of } 0.6 \mathrm{ml}\end{array}$ & $\begin{array}{l}\$ 8,402.23 \text { for } 1 \\
\text { syringe of } \\
\text { Neulasta } \\
(6 \mathrm{mg} / 0.6 \mathrm{ml})\end{array}$ \\
\hline
\end{tabular}




\begin{tabular}{|c|c|c|c|c|}
\hline $\begin{array}{l}\text { Product } \\
\text { Name }\end{array}$ & $\begin{array}{l}\text { Average Price on } \\
\text { Drugs.com }\end{array}$ & $\begin{array}{c}\text { Average } \\
\text { Price on } \\
\text { GoodRX.com }\end{array}$ & $\begin{array}{c}\text { Average Price of } \\
\text { Reference Product on } \\
\text { Drugs.com }\end{array}$ & $\begin{array}{l}\text { Average Price of } \\
\text { Reference } \\
\text { Product on } \\
\text { GoodRX.com }\end{array}$ \\
\hline Truxima & $\begin{array}{c}\text { Truxima intravenous solution } \\
\text { (abbs } 10 \mathrm{mg} / \mathrm{ml} \text { ) is around } \\
\$ 892.25 \text { for a supply of } 10 \\
\mathrm{ml}\end{array}$ & N/A & $\begin{array}{l}\text { Rituxan intravenous } \\
\text { solution }(10 \mathrm{mg} / \mathrm{ml}) \text { is } \\
\text { around } \$ 990.36 \text { for a } \\
\text { supply of } 10 \mathrm{ml}\end{array}$ & $\mathrm{N} / \mathrm{A}$ \\
\hline Ruxience & N/A & N/A & $\begin{array}{l}\text { Rituxan intravenous } \\
\text { solution }(10 \mathrm{mg} / \mathrm{ml}) \text { is } \\
\text { around } \$ 990.36 \mathrm{for} \text { a } \\
\text { supply of } 10 \mathrm{ml}\end{array}$ & N/A \\
\hline Kanjinti & $\begin{array}{l}\text { Kanjinti intravenous powder } \\
\text { for injection anns } 150 \mathrm{mg} \text { is } \\
\text { around } \$ 1,388.05 \text { for a } \\
\text { supply of } 1 \text { powder for } \\
\text { injection }\end{array}$ & N/A & $\begin{array}{l}\text { Herceptin intravenous } \\
\text { powder for injection } 150 \\
\mathrm{mg} \text { is around } \$ 1,636.49 \\
\text { for a supply of } 1 \text { powder } \\
\text { for injection }\end{array}$ & N/A \\
\hline Ogivri & $\begin{array}{l}\text { Ogivri intravenous powder } \\
\text { for injection dkst } 150 \mathrm{mg} \text { is } \\
\text { around } \$ 1,392.44 \text { for a } \\
\text { supply of } 1 \text { powder for } \\
\text { injection }\end{array}$ & N/A & $\begin{array}{l}\text { Herceptin intravenous } \\
\text { powder for injection } 150 \\
\mathrm{mg} \text { is around } \$ 1,636.49 \\
\text { for a supply of } 1 \text { powder } \\
\text { for injection }\end{array}$ & N/A \\
\hline Ontruzant & N/A & N/A & $\begin{array}{l}\text { Herceptin intravenous } \\
\text { powder for injection } 150 \\
\mathrm{mg} \text { is around } \$ 1,636.49 \\
\text { for a supply of } 1 \text { powder } \\
\text { for injection }\end{array}$ & N/A \\
\hline Herzuma & N/A & N/A & $\begin{array}{l}\text { Herceptin intravenous } \\
\text { powder for injection } 150 \\
\mathrm{mg} \text { is around } \$ 1,636.49 \\
\text { for a supply of } 1 \text { powder } \\
\text { for injection }\end{array}$ & N/A \\
\hline Trazimera & N/A & N/A & $\begin{array}{l}\text { Herceptin intravenous } \\
\text { powder for injection } 150 \\
\mathrm{mg} \text { is around } \$ 1,636.49 \\
\text { for a supply of } 1 \text { powder } \\
\text { for injection }\end{array}$ & N/A \\
\hline
\end{tabular}


TABLE III

\begin{tabular}{|c|c|c|c|c|c|c|c|c|c|}
\hline $\begin{array}{c}\text { Product } \\
\text { Name }\end{array}$ & $\begin{array}{c}\text { Price } \\
\text { Per } \\
\text { Month } \\
\text { (in \$) }\end{array}$ & $\begin{array}{c}\text { \% Lower } \\
\text { than } \\
\text { Reference } \\
\text { Product in } \\
\text { Early 2020 } \\
\text { (Drugs.com } \\
\text { prices/other } \\
\text { sources) }\end{array}$ & $\begin{array}{l}\text { \% Lower } \\
\text { than } \\
\text { Reference } \\
\text { Product in } \\
\text { Early } 2020 \\
\text { (Good Rx }^{\text {prices) }}{ }^{73}\end{array}$ & $\begin{array}{l}\text { Reference } \\
\text { Date of } \\
\text { Approval }\end{array}$ & $\begin{array}{l}\text { Reference } \\
\text { Years of } \\
\text { Exclusivity } \\
\text { Before } \\
\text { Biosimilar } \\
\text { Approval }\end{array}$ & $\begin{array}{l}\text { Reference } \\
\text { Years of } \\
\text { Exclusivity } \\
\text { Before 1st } \\
\text { Biosimilar } \\
\text { Approval }\end{array}$ & $\begin{array}{l}\text { Reference } \\
\text { Years of } \\
\text { Exclusivity } \\
\text { Before 1st } \\
\text { Biosimilar } \\
\text { Launch }\end{array}$ & $\begin{array}{c}\text { Approved } \\
\text { Biosimilars } \\
\text { per } \\
\text { Reference } \\
\text { Product }\end{array}$ & $\begin{array}{c}\text { Launched } \\
\text { Biosimilars } \\
\text { per } \\
\text { Reference } \\
\text { Product }\end{array}$ \\
\hline Hyrimoz & & & & $12 / 31 / 2002$ & 15.75 & \multirow{5}{*}{13.67} & & \multirow{5}{*}{5} & \multirow{5}{*}{0} \\
\hline Cyltezo & & & & $12 / 31 / 2002$ & 14.58 & & & & \\
\hline Abrilada & & & & $12 / 31 / 2002$ & 16.83 & & & & \\
\hline Amjevita & & & & $12 / 31 / 2002$ & 13.67 & & & & \\
\hline Hadlima & & & & $12 / 31 / 2002$ & 16.50 & & & & \\
\hline Mvasi & 10,161 & $14.83 \%$ & $15 \%$ & $2 / 26 / 2004$ & 13.50 & \multirow{2}{*}{13.50} & \multirow{2}{*}{15.33} & \multirow{2}{*}{2} & \multirow{2}{*}{2} \\
\hline Zirabev & 9,201 & N/A & $23 \%$ & $2 / 26 / 2004$ & 15.33 & & & & \\
\hline Retacrit & 992 & $32.58 \%$ & $80 \%$ & $6 / 1 / 1989$ & 28.92 & 28.92 & 29.42 & 1 & 1 \\
\hline Erelzi & & & & $11 / 2 / 1998$ & 17.75 & \multirow{2}{*}{17.75} & & \multirow{2}{*}{2} & \multirow{2}{*}{0} \\
\hline Eticovo & & & & $11 / 2 / 1998$ & 20.42 & & & & \\
\hline
\end{tabular}

${ }^{73}$ See Lauren Chase, A Guide to Biosimilar Prices: How Much They Cost and How You Can Save, GoodRx BlOG (Apr. 14, 2020, 11:32 AM), https://www.goodrx.com/blog/biosimilars-prices-how-muchthey-cost-how-to-save/ [https://perma.cc/E5F8-3WAR]. 


\begin{tabular}{|c|c|c|c|c|c|c|c|c|c|}
\hline $\begin{array}{l}\text { Product } \\
\text { Name }\end{array}$ & $\begin{array}{l}\text { Price } \\
\text { Per } \\
\text { Month } \\
\text { (in \$) }\end{array}$ & $\begin{array}{l}\text { \% Lower } \\
\text { than } \\
\text { Reference } \\
\text { Product in } \\
\text { Early } 2020 \\
\text { (Drugs.com } \\
\text { prices/other } \\
\text { sources) }\end{array}$ & $\begin{array}{l}\text { \% Lower } \\
\text { than } \\
\text { Reference } \\
\text { Product } \\
\text { in Early } \\
2020 \\
\text { (Good Rx } \\
\text { prices) }\end{array}$ & $\begin{array}{c}\text { Reference } \\
\text { Date of } \\
\text { Approval }\end{array}$ & $\begin{array}{l}\text { Reference } \\
\text { Years of } \\
\text { Exclusivity } \\
\text { Before } \\
\text { Biosimilar } \\
\text { Approval }\end{array}$ & $\begin{array}{c}\text { Reference } \\
\text { Years of } \\
\text { Exclusivity } \\
\text { Before 1st } \\
\text { Biosimilar } \\
\text { Approval }\end{array}$ & $\begin{array}{l}\text { Reference } \\
\text { Years of } \\
\text { Exclusivity } \\
\text { Before 1st } \\
\text { Biosimilar } \\
\text { Launch }\end{array}$ & $\begin{array}{c}\text { Approved } \\
\text { Biosimilars } \\
\text { per } \\
\text { Reference } \\
\text { Product }\end{array}$ & $\begin{array}{c}\text { Launched } \\
\text { Biosimilars } \\
\text { per } \\
\text { Reference } \\
\text { Product }\end{array}$ \\
\hline Nivestym & 438 & $33.46 \%$ & $37 \%$ & 2/20/1991 & 27.42 & \multirow[t]{2}{*}{16.50} & \multirow[t]{2}{*}{17.00} & \multirow{2}{*}{2} & \multirow[t]{2}{*}{2} \\
\hline Zarxio & 549 & $30.32 \%$ & $18 \%$ & $8 / 24 / 1998$ & 16.50 & & & & \\
\hline Renflexis & 3,014 & $35.21 \%$ & $35 \%$ & $8 / 24 / 1998$ & 18.58 & \multirow{4}{*}{17.58} & \multirow{4}{*}{18.25} & \multirow{4}{*}{4} & \multirow{4}{*}{2} \\
\hline Avsola & & & & 8/24/1998 & 21.25 & & & & \\
\hline Inflectra & 3,785 & $18.82 \%$ & $19 \%$ & $8 / 24 / 1998$ & 17.58 & & & & \\
\hline Ixifi & & & & 8/24/1998 & 19.25 & & & & \\
\hline
\end{tabular}




\begin{tabular}{|c|c|c|c|c|c|c|c|c|c|}
\hline $\begin{array}{c}\text { Product } \\
\text { Name }\end{array}$ & $\begin{array}{l}\text { Price } \\
\text { Per } \\
\text { Month } \\
\text { (in \$) }\end{array}$ & $\begin{array}{l}\text { \% Lower } \\
\text { than } \\
\text { Reference } \\
\text { Product in } \\
\text { Early } 2020 \\
\text { (Drugs.com } \\
\text { prices/other } \\
\text { sources) } \\
\end{array}$ & $\begin{array}{c}\text { \% Lower } \\
\text { than } \\
\text { Reference } \\
\text { Product } \\
\text { in Early } \\
2020 \\
\text { (Good Rx } \\
\text { prices) }\end{array}$ & $\begin{array}{l}\text { Reference } \\
\text { Date of } \\
\text { Approval }\end{array}$ & $\begin{array}{l}\text { Reference } \\
\text { Years of } \\
\text { Exclusivity } \\
\text { Before } \\
\text { Biosimilar } \\
\text { Approval }\end{array}$ & $\begin{array}{c}\text { Reference } \\
\text { Years of } \\
\text { Exclusivity } \\
\text { Before 1st } \\
\text { Biosimilar } \\
\text { Approval }\end{array}$ & $\begin{array}{l}\text { Reference } \\
\text { Years of } \\
\text { Exclusivity } \\
\text { Before 1st } \\
\text { Biosimilar } \\
\text { Launch }\end{array}$ & $\begin{array}{c}\text { Approved } \\
\text { Biosimilars } \\
\text { per } \\
\text { Reference } \\
\text { Product }\end{array}$ & $\begin{array}{c}\text { Launched } \\
\text { Biosimilars } \\
\text { per } \\
\text { Reference } \\
\text { Product }\end{array}$ \\
\hline Ziextenzo & 3,926 & $36.95 \%$ & $37 \%$ & $1 / 31 / 2002$ & 17.75 & \multirow{3}{*}{16.33} & \multirow{3}{*}{16.42} & \multirow{3}{*}{3} & \multirow{3}{*}{3} \\
\hline Udenyca & 4,175 & $32.95 \%$ & $33 \%$ & $1 / 31 / 2002$ & 16.75 & & & & \\
\hline Fulphila & 4,175 & $32.95 \%$ & $33 \%$ & $1 / 31 / 2002$ & 16.33 & & & & \\
\hline Truxima & 2,198 & $9.91 \%$ & $9 \%$ & $11 / 26 / 1997$ & 21.00 & \multirow{2}{*}{21.00} & \multirow{2}{*}{21.92} & \multirow{2}{*}{2} & \multirow{2}{*}{2} \\
\hline Ruxience & 1,863 & $\mathrm{~N} / \mathrm{A}$ & $24 \%$ & 11/26/1997 & 21.58 & & & & \\
\hline Kanjinti & 3,961 & $15.18 \%$ & $15 \%$ & $9 / 25 / 1998$ & 20.67 & \multirow{5}{*}{19.17} & \multirow{5}{*}{20.75} & \multirow{5}{*}{5} & \multirow{5}{*}{4} \\
\hline Ogivri & 3,974 & $14.91 \%$ & $15 \%$ & 9/25/1998 & 19.17 & & & & \\
\hline Ontruzant & & & & $9 / 25 / 1998$ & 20.25 & & & & \\
\hline Herzuma & 4,208 & $10 \%$ & $10 \%$ & $9 / 25 / 1998$ & 20.17 & & & & \\
\hline Trazimera & 3,391 & $22 \%$ & $27 \%$ & 9/25/1998 & 20.42 & & & & \\
\hline
\end{tabular}

